\title{
Determinants of Performance of MSMEs in the Era of Industrial Revolution 4.0 in Medan City
}

\author{
Jantri K Saragih ${ }^{1)}$, Romindo M Pasaribu ${ }^{2)}$, Juara Simanjutak ${ }^{3)}$, Herry D.S. Pasaribu ${ }^{4)}$, \\ Vincensius Matondang ${ }^{5)}$ \\ 1), 3), 4) Universitas HKBP Nommensen, Indonesia \\ ${ }^{2)}$ FEB, Universitas HKBP Nommensen, Indonesia \\ 5) Politeknik Wilmar Bisnis Indonesia, Indonesia
}

Email: jantrisaragih242@gmail.com ${ }^{1)}$,megawati.pasaribu@gmail.com²), juara_juntak@yahoo.co.id ${ }^{3)}$.herry.pasaribu@gmail.com ${ }^{4)}$, vinsensius.matondang@wbi.ac.id ${ }^{5)}$

\begin{abstract}
The existence of Micro, Small, and Medium Enterprises (MSMEs) is the largest part of the national economy, this is proven that MSMEs can be relied upon as a foundation in times of crisis such as the Covid-19 period. Constraints that are often experienced by MSME actors include establishing partnerships with third parties in terms of capital, making innovations in the face of market competition. The purpose of this study is to find out how business networks, product innovation, and business competition affect business performance for MSME actors in the city of Medan. This type of research is quantitative research by distributing questionnaires and observing MSME actors. The number of samples in this study was 94 business actors in the city of Medan. The results showed that the business network variable had an insignificant effect on the business performance variable. Product innovation and business competition variables have a significant influence on business performance. Viewed from R2, it shows that business networks, product innovation, and business competition are able to explain business performance by $37.8 \%$.
\end{abstract}

Keywords: business network, product innovation, business competition, business performance, MSME

\section{Introduction}

The industrial revolution 4.0 is often referred to as a cyber physical system which is a revolution that focuses on automation and collaboration between cyber technologies. Revolution 4.0 emerged in the 21 st century with the main characteristic of merging information and communication technology into the industrial sector. With the advent of the 4.0 revolution, it has changed many things in various sectors. Where at first, it required a lot of manpower to carry out operational activities, but now it is replaced by the use of technological machines. The types of technology contained in the 4.0 revolution include; Internet of Things atau IoT, Big Data, Augmented Reality, Cyber Security, Artificial Intelligence atau AI, Additive Manufacturin, Simulation, System Integration, dan Cloud computing.

To be able to survive in the industry, MSME actors must start using technology in every production process. The use of technology can be done to reduce production costs, promotions, and other costs. With this technology, it is easier for MSME actors to obtain information and build partnerships with parties who are considered capable of advancing their business development. Technological developments also make it easier for MSME actors to establish cooperation or business networks with third parties related to capital and other 
information. Business networks have an important role in the development of a business. Business networks are needed to find and find customers to build good relationships between the two.

In addition, technological developments can also be used to make improvements and changes to the products to be produced. To produce products that are in accordance with the wants and needs of the market, market research is needed. Market research can be done by finding as much information as possible on the internet, social networks, google trends, and others. One step to deal with changing market needs and wants is to innovate. Innovation is the intentional introduction and application in work, organization of new ideas, processes or procedures in work, work teams or organizations designed to benefit the job. Product innovation is defined as the efforts made by business actors to improve, improve, and develop the products they produce.

Innovation can be used as a tool to win business competition. Business competition is the efforts of two or more companies, each of which strives to obtain orders by offering the most favorable prices. Business competition is carried out to win the hearts of consumers, where business actors try to offer attractive products and services, both in terms of price, quality, and service.

The formulation of the problem in this study is whether business networks, product innovation, and business competition affect the business performance of MSMEs in Medan City? And the purpose of this study is to find out how business networks, product innovation, and business competition affect the business performance of MSMEs in Medan City.

\section{Literature Review}

\subsection{Business Performance}

Performance refers to the level of achievement or achievement of the company in a certain period of time. The company's goals which consist of: staying standing, to earn a profit and can develop can be achieved if the company has a good performance (Suci, 2009). Performance is a quantitative and qualitative measure that describes the level of achievement of a target or goal that has been set by the organization (Moeheriono, 2012:32). Gibson, et. al (2013) said that performance is a series of management activities that provide an overview of the extent to which the results have been achieved in carrying out their duties and responsibilities in the form of public accountability, both in the form of successes and shortcomings that occur. The achievement of the results of a series of activities in question includes work standards, targets or targets or criteria that have been determined since the start of the business. Zaenal and Laksana (2015: 183) state that there are 3 business performance indicators, namely:

1. Effectiveness is the relationship between output and goals, where effectiveness is measured based on how far the level of output, policies and procedures of the organization achieve the goals set.

2. Efficiency is the relationship between inputs and outputs where users of goods and services are purchased by the organization to achieve certain outputs.

3. Economical is the relationship between markets and inputs, where the purchase of goods and services is carried out at the desired quality and the best possible price.

\subsection{Business Network}

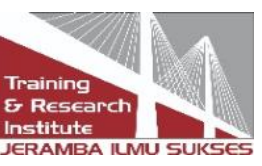


Kotler and Armstrong (2012:41), business networks involve other business units in business activities carried out by producers, both in production activities and product marketing. Producers use intermediaries because they create greater efficiency in providing goods to target markets through contacts, experience, specialization and scale of operation, intermediaries usually offer the company more than what the company can achieve on its own. Lestari, et al (2015:4) Business networks are all relationships that help in the formation of a new business as part of a network. Susilowati and Taufan (2013:03) business network is the ability of network ties (networkties) to connect actors with various businesses such as: business partners, friends, agents, mentors to get the resources needed such as information, money, moral support for network actors. From the above understanding, it can be concluded that a business network is something that needs to be developed so that it becomes a broad business and relationships or contacts with many people for the purpose of developing a business. Nur (2015) formulates business performance indicators, namely:

1. The breadth of the marketing network, is the ability of business actors to disseminate marketing networks so that consumers can find out their ongoing businesses in the community.

2. The breadth of the service network, is a service provided by business actors to customers with the aim of retaining customers so that customers are comfortable in their line of business.

3. The breadth of the network of cooperation, is the ability of business actors towards other business actors by establishing cooperation so that each business actor is closely related.

4. The extent of the network between business groups, is part of the groups that are trying to build a network so that each small group can compete against the big group.

5. The breadth of the network in solving problems and challenges, is the ability of business actors to solve problems that occur without causing harm to other parties.

\subsection{Product Innovation}

Lestari, et al (2015; 05), innovation includes a new concept, implementation, and evaluation whose ultimate goal is the commercialization of the idea. In a business context, innovation is a company's efforts to take advantage of advances in technology and information, to modify ideas to commercialize products to the market, with the ultimate goal of meeting consumer needs. Sukarmen, et al, $(2013 ; 68)$, product innovation is something that can be seen as a product's functional progress one step ahead of its competitors' products. Product innovation is the provision of changes to marketed products with efforts to increase quality and quantity aimed at retaining customers or consumers. According to Hunger and L. Wheellen (in Wahid and Santoso, 2019) product innovation indicators are:

1. Design changes, namely the renewal of product patterns. Design changes aim to retain customers or consumers by providing changes to products to become more attractive.

2. Technical innovation, namely renewal in terms of service to consumers, is an increase in services provided to consumers such as the application of $3 \mathrm{~S}$, namely: smile, greeting and greeting. Thus consumers will feel comfortable.

3. Product development, namely changes and updates of existing products, is to provide improvements related to products that are less desirable by consumers so that products that are in business meet customer expectations. 


\subsection{Business Competition}

Business competition can influence policies related to trade, industry, conducive business climate, business certainty and opportunity, efficiency, public interest, and people's welfare. According to the law, the commission for supervising business competition is competition between business actors in carrying out production and or marketing activities of goods and services. Business competition is a picture or pattern that determines whether a business can maintain its course for how long the business can survive for a predetermined period of time, for that it is very necessary to have good cooperation between business actors, both with fair competition and unfair competition. Damuri, et al (2017:03) there are several indicators of business competition, namely:

1. Market structure and concentration ratio, in industrial economic theory, a study of structure, conduct and performance is carried out to see the relationship between market structure and the performance of the firms in it. One of the market measuring tools is concentration which also describes the amount of market power in several companies and describes the intensity of competition

2. The history of business competition policy, policies related to investment by creating a barrier to entry for foreign investors also affect the level of competition in the country.

3. Industry concentration trends, trend ratio analysis to find out market-centered concentration in Indonesia.

4. Business competition in the service sector, the service sector also has a very significant contribution to inputs from other sectors to produce more efficiently

\subsection{Hypotheses Development}

The business network involves other business units in business activities carried out by producers, both in production activities and product marketing. Producers use intermediaries because they create greater efficiency in providing goods to target markets. Through contacts, experience, specialization, and scale of operation, intermediaries usually offer the company more than what the company can achieve on its own (Kotler and Armstrong, 2012: 41). Hendriyanto's research (2015) on the analysis of business networks and innovation on the performance of MSMEs, where the business network has a positive influence on the performance of MSMEs. This shows that the better the business network owned by MSMEs, the higher their business performance. Then the hypothesis can be formulated as follows

H1: There is a significant relationship between business networks and MSME performance.

Product innovation is something that can be seen as a product's functional progress. Every business actor is required to innovate or change the goods being marketed, either adding quantity, increasing the quality of a product so that consumers feel satisfied and give more hope to the products being marketed. Thus, SMEs must make changes to each product. To make changes to the product requires no small amount of money so that it takes the creativity of business owners to innovate products that can affect business performance

Innovation consists of technical, physical and knowledge processes whose primary purpose is to develop products. Innovation has the benefit of creating value of new proportions through a range such as offering new products or services, adopting new organizational and operational practices, providing technological solutions or creating new skills and competencies. In addition, innovation can also encourage the skills and knowledge needed to effectively 
realize, master and improve existing technologies, and to create something new (Ofori and Daniel (2015). Research by Ulfah and Semiyawati (2020), on the influence of innovation and strategic planning on the performance of micro, small and medium enterprises (MSMEs), where product innovation has a significant effect on the business performance of MSMEs, so the hypothesis can be formulated as follows:

$\mathrm{H} 2$ : There is a significant relationship between product innovation and MSME performance

Lubis (2017: 51), business competition can influence policies related to trade, industry, a conducive business climate, business certainty and opportunity, efficiency, public interest, people's welfare and so on. Thus, it is hoped that MSME actors can conduct healthy business competition in the sense that each business actor does not bring each other down among business actors but supports each other for the progress of micro, small and medium enterprises. . Then the hypothesis can be formulated as follows:

H3: There is a significant relationship between business competition and the performance of SMEs

\section{Research Method}

The type of research in this study is quantitative research, namely research that aims to determine the relationship between two or more variables, (Sugiyono, 2017:05). The variables connected in this study are independent variables, namely business networks, product innovation, and business competition with the dependent variable being business performance. The location of this research was conducted in the city of Medan. The time of research was carried out in February 2021 until it was completed.

The population in this study amounted to 1447 SMEs in the city of Medan. Sampling using the Slovin formula was obtained as many as 94 respondents. The sampling technique is based on the probability sampling technique with simple random sampling, in which the researcher provides equal opportunities for each MSME actor to be selected as a random sample without regard to the strata that exist in the population itself. The data analysis technique used to answer the hypothesis is the multiple regression analysis methods. Multiple regression analysis is used to prove whether there is a causal relationship between the independent variable $(\mathrm{X})$ and the dependent variable $(\mathrm{Y})$, so the independent variable $(\mathrm{X})$ is 2 or more.

\section{Findings and Discussions}

\subsection{Findings}

The multiple regression analysis methods are used to prove whether there is a causal relationship between the independent variables (business network, product innovation, business competition) and the dependent variable (business performance). The following are the results of multiple regression tests to answer the hypothesis:

Table 1. Multiple regression analysis

\begin{tabular}{|l|r|r|c|c|c|}
\hline \multirow{2}{*}{ Model } & \multicolumn{2}{|c|}{$\begin{array}{c}\text { Unstandardized } \\
\text { Coefficients }\end{array}$} & $\begin{array}{c}\text { Standardized } \\
\text { Coefficients }\end{array}$ & & \\
\cline { 2 - 6 } & \multicolumn{1}{|c|}{ B } & Std. Error & Beta & $\mathrm{t}$ & Sig \\
\hline (Constant) & 10.929 & 2.649 & & 4.126 & .000 \\
\hline
\end{tabular}




\begin{tabular}{|l|r|r|r|r|l|}
\hline Business Network & .196 & .102 & .178 & 1.934 & .056 \\
\hline Product Innovation & .343 & .108 & .294 & 3.165 & .002 \\
\hline Business competition & .368 & .113 & .326 & 3.241 & .002 \\
\hline
\end{tabular}

Based on table 1, the following regression equation is obtained:

$\mathrm{Y}=10,929+0,196 \mathrm{X} 1+0,343 \mathrm{X} 2+0,368 \mathrm{X} 3$

From the above equation it can be interpreted that:

1. Constant : 10.929 this means that if the independent variable (business network, product innovation, business competition), then the value of the dependent variable (business performance) is $=10.929$

2. $\beta 1: 0.196$. The regression coefficient of the business network is 0.196 , which means that if there is a change in the business network, it will increase the value of business performance by 0.196 . Assuming other variables are fixed.

3. $\beta 2: 0.343$. The regression coefficient of product innovation is 0.343 , which means that if there is a change in product innovation, it will increase the value of business performance by 0.196 . Assuming other variables are fixed.

4. $\beta 2: 0.368$. The regression coefficient of business competition is 0.368 , which means that if there is a change in business competition, it will increase the value of business performance by 0.368 . Assuming other variables are fixed.

From the regression explanation above, it can be concluded that the business competition variable has a stronger influence in influencing the business performance of MSMEs in Medan City. This can be seen from the regression coefficient value, which has a regression coefficient value of 0.368 for the business competition variable, which is greater than the regression coefficient for other variables.

Based on the results of the statistical tests in table 8 above, it can be seen that the results of tests carried out partially independent of each dependent variable.

1. The business network variable has a positive and insignificant effect on the business performance of MSMEs in the city of Medan. This can be seen from the sig value where the sig value is $0.056>0.05$. Thus, the first hypothesis is rejected.

2. The product innovation variable has a positive and significant influence on the business performance of MSMEs in the city of Medan. This can be seen from the sig value where the sig value is $0.002<0.05$. Thus, the second hypothesis is accepted.

3. The business competition variable has a positive and significant influence on the business performance of MSMEs in Medan City. This can be seen from the value of sig where sig is $0.002<0.05$. Thus, the third hypothesis is accepted.

Based on the statistical test, F basically shows whether all independent or independent variables included in the model have a joint effect on the dependent or dependent variable. 
Tabel 2. Uji simultan (F)

ANOVA $^{\mathrm{a}}$

\begin{tabular}{|l|r|r|r|r|r|}
\hline Model & Sum of Squares & Df & Mean Square & F & Sig. \\
\hline 1 Regression & 590.193 & 3 & 196.731 & 18.247 & $.000^{\mathrm{b}}$ \\
Residual & 970.361 & 90 & 10.782 & & \\
Total & 1560.553 & 93 & & & \\
\hline
\end{tabular}

a. Dependent Variable: business performance

b. Predictors: (Constant), product innovation, business competition, business network

Based on the results of data processing above, it can be concluded that simultaneously the independent variables (business network, product innovation, and business competition) have a positive and significant effect on the independent variable (business performance). This can be seen from the significance value $<0.05$, namely $18.24<0.05$, so the fourth hypothesis is accepted.

The coefficient of determination test for R2 is carried out to measure the level of how much the independent variable explains the dependent variable. The value of the coefficient of determination is between 0 and $1(0<\mathrm{R} 2<1)$. To facilitate data processing, the above tests were carried out using the SPSS data processing program.

Tabel 3. Coefficient of determination R2

\begin{tabular}{|l|r|r|r|r|r|}
\hline Model & \multicolumn{1}{|c|}{$\mathrm{R}$} & \multicolumn{1}{|c|}{ R Square } & $\begin{array}{c}\text { Adjusted } \\
\text { R Square }\end{array}$ & $\begin{array}{c}\text { Std. Error of the } \\
\text { Estimate }\end{array}$ & Durbin-Watson \\
\hline 1 & $.615^{\mathrm{a}}$ & .378 & .357 & 3.284 & 1.921 \\
\hline
\end{tabular}

a. Predictors: (Constant), Product Innovation, Business Competition, Business Network

\section{b. Dependent Variable: Business Performance}

Based on the table 3, it states that the coefficient of determination (R2) is 0.378 or close to $37.8 \%$. This means that if changes occur in the independent variables (business network, product innovation, business competition) to the dependent (business performance) the remaining 0.6225 or $62.25 \%$ influenced by other factors.

\subsection{Discussions}

The development of a business network is one of the things that is very good for the development of MSME business performance in the city of Medan. MSMEs that have a strong business network will certainly develop faster and have maximum performance 
compared to MSMEs that do not have a good business network. In this study, there are 3 indicators of business networks, namely service networks, cooperation networks, and networks between business groups.

From the results of the questionnaire and respondent's description, it was found that the service network provided by MSME business actors in the city of Medan was still not optimal. This condition will certainly have an impact on business performance because the weak service network owned by MSME actors will reduce MSME business performance in Medan City. From the cooperation network, MSME business actors have been able to develop a network of cooperation with fellow business actors well. From the network between business groups, the ability of business actors to be able to compete with larger business actors is still less than optimal, this is due to encouragement from the government such as the direct cash assistance (BLT) budget that is appropriate for each business actor, starting from MSME start-ups, business micro, small and medium enterprises.

Product innovation is one of the most important factors in retaining and attracting consumers so that consumers feel at home so as to maintain and encourage the increased business performance of MSMEs. Lestari, et al (2019; 05), innovation includes a new concept, implementation, and evaluation whose ultimate goal is the commercialization of the idea.

From the results of the questionnaire, it was found that MSME business actors in the city of Medan were quite active in making changes to the design of the products they sold. Business actors are active in following market development trends so that they can adapt to market conditions and consumer needs. With these conditions, it will have a very good impact on the business performance of MSMEs in the city of Medan. MSME business performance will increase and develop much better.

From the aspect of technical innovation, innovation is also very closely related to morality. With ethics that can give a friendly impression, every customer in the business environment that we run will be more comfortable and maintain good relations. It is also very possible with the influence of the government by holding exhibitions such as the Tourism and Creative Economy Agency (Bekraf). every business actor will be higher to look for variants that make people like the product, therefore the business performance of each business actor will grow for the better, of course, it also greatly contributes to the level of economic progress in Indonesia, especially in the city of Medan.

The tight business competition will certainly encourage every business actor to improve business performance to the maximum. Every business actor will try his best to be able to give his best ability so that the products marketed can be ogled and liked by many consumers.

From the results of the questionnaire and descriptions of respondents' answers, it can be seen that MSME business actors already know the structure of the market they will enter and are also able to concentrate on the business they will run. MSME business actors are able to understand the structure of the market they will enter so that business actors can establish business policies and strategies to be able to win a fairly tight business competition.

In terms of the history of business competition policy, MSME business actors do not consider past business competition policies in setting business competition policies at this time. From the results of the questionnaire, it was found that business actors set business policies based on current conditions and developments. Business actors tend not to consider past policies to determine current policies. This condition certainly has an impact on the business 
performance of each MSME business actor. Competition policies in the past may be useful for current conditions, so it is also necessary to reconsider so that every MSME business actor can make the right policy so that it will encourage the growth of MSME business performance.

\section{References}

Damuri, et al. (2017). Kondisi persaingan usaha di Indonesia 1997-2012: Analisis konsentrasi industri dan iklim regulasi. Centre for Strategic and International Studies.

Gary, A dan Kotler, P. (2012). Dasar-Dasar Pemasaran. Jilid I, Alih Bahasa Alexander Sindoro dan Benyamin Molan. Jakarta: Prenhalindo.

Gibson, et al. (2013). Manajemen Sumber Daya Manusia, Edisi Keempat. Jakarta: Erlangga.

Hendriyanto, A. (2015). Analisis Pengaruh Jaringan Usaha dan Inovasi Terhadap Kinerja UMKM. Jurnal Ilmu Manajemen dan Akuntansi Terapan (JIMAT). Vol,6. No.1, pp.4449. ISSN:2656-4440.

Lestari, et al. (2015). Pengaruh Jaringan Usaha, Inovasi Produk Dan Persaingan Usaha Terhadap Perkembangan Usaha Mikro, Kecil Dan Menengah (Studi pada IKM Makanan di Kecamatan Kuningan Kabupaten Kuningan Jawa Barat). Jurnal Anorag, Vol.1 No.1, hal 1-12

Lubis, Andi Fahmi. (2015). Hukum Persaingan Usaha Antara Teks \& Konteks. Jakarta: Deutsche Gesellschaft für Technische Zusammenarbeit (GTZ) GmbH, 2009.

Moeheriono. (2012). Pengukuran Kinerja Berbasis Kompetensi, edisi revisi, cetakan pertama. Jakarta: Raja Grafindo Persada.

Nur, A. W. (2015). Analisis Pengaruh Orientasi Wirausaha, Kapabilitas Pencitraan terhadap Jaringan Usaha dan Keunggulan Bersaing serta Dampak pada Kinerja Perusahaan. Jurnal Ilmu Riset Pemasaran, vol. 1 no. 1

Ofori, D. et al. (2015). Innovation and Knowledge Sharing : A New Competitive Advantage in the Mobile Telecommunication Industry in Ghana, Science Journal of Business and Management, Vol. 3, No. 5, pp.157-163.

Susilowati, E. M. dan Taufan, G. (2013). Pengembangan Jejaring Wirausaha dan Pembelajaran Eksploratif Sebagai Upaya Meningkatkan Kinerja Perekonomian Unit Usaha Kecil Menengah di Semarang. Jurnal Emba, Vol.2 No.3. Hal.1-15

Suci. (2009). Pengaruh Kewirausahaan terhadap Kinerja Usaha Tani Tembakau di Kecamatan Gantawarrno Kabupaten Klaten. Jurnal Aplikasi Manajmen, Vol 7 no 2.

Sukarmen, et al. (2013). Analisis Pengaruh Produk terhadap Kepuasan Konsumen dengan Keunggulan Bersaing sebagai Variabel Intervening pada Produk Gula Pasir Sebelas (GULAPAS). Pabrik Sembrono PTP Nusantara XI (PERSERO), JEAM, Vol. XII, No.1. ISSN: 1412-5366.

Sugiyono. (2017). Metode Penelitian Kuantitatif, Kualitatif, dan R\&D. Bandung: Alfabeta,

Ulfah, A dan Desmiyawati. (2020). Pengaruh Inovasi dan Perencanaan Strategi Terhadap Kinerja Usaha Mikro Kecil dan Menengah (UMKM) (Studi Empiris Pada UMKM di Kabupaten Rokan Hulu). Review of Accounting and Business, Vol.1, No. 1. 
Wahid, A., \& Santoso, T. I. (2019). Pengaruh Harga dan Inovasi Produk Terhadap Minat beli Konsumen pada PT INDACO warna Dunia Di Kota Batam. SCIENTIA JOURNAL: Jurnal Ilmiah Mahasiswa, 1(2).

Zaenal, M dan Laksana, M.W. (2015). Manajemen Pelayanan Publik. Bandung: CV Pustaka Setia. 